\title{
Mirroring To The Greek's Tourism after Economy Crisis: The Effect of Tourism Sector to Bangka Belitung GDRP
}

\author{
Royhan Faradis $^{1^{*}}$ \& Uswatun Nurul Afifah ${ }^{1}$ \\ ${ }^{1}$ Statistics of Belitung Timur Regency, Jalan Raya Manggarawan, Manggar, Belitung Timur 55316, \\ Indonesia; *Corresponding author. e-mail: royhan.faradis@bps.go.id \\ (Received: 23 February 2018; Accepted: 23 July 2018)
}

\begin{abstract}
High dependency on tin mining is an economic problem in Bangka Belitung Islands province. The peak came after the issuance of tin mining restriction law almost a decade ago, hence Bangka Belitung is currently experiencing a slowdown in the rate of economic growth on an ongoing basis. One way out of this economic problem is to rely on tourism, since the demographically and geographically Bangka Belitung is a world tourist paradise. However, bad tourism management will actually increase development losses. Therefore, this paper will discuss the influence of Bangka Belitung tourism on its economy if tourism were a leading sector as applied in Greece in recent years. In addition, the characteristics of Greece, Santorini in this case, is not much different from Bangka Belitung Islands. In getting the answer from this problem, two methods of analysis are done, namely the Strength, Weakness, Opportunity and Threat (SWOT) table and the formation of simple regression model related to tourism and economy of Bangka Belitung. The results obtained shows that Bangka Belitung's economy will grow positively due to its tourism influence, and with similar characteristics of Bangka Belitung with Santorini then the "4S tourism policy" (sun, sea, sand and seafood) can be applied in Bangka Belitung.
\end{abstract}

Keywords: Babel Tourism, SWOT, Simple Liner Regression, 4S Santorini

\section{INTRODUCTION}

Bangka Belitung Islands province, Indonesia, experienced a slowdown in economic growth rates over the last five years. Statistics (Badan Pusat Statistik) explain the economy growth in 2012 is $6.05 \%$ and always decrease until $4,19 \%$ in $2016^{2}$. Although the growth is still positive, this situation will get worse year by year if there is no action to prevent this slowdown. The main reason is the large dependence of economic activity towards the manufacturing industry, agriculture, and plantations, as well as quarrying and mining. In fact, since the Law No.22/1999 about Regional Autonomy and Industry \& Trade Ministry Law No.146/MPP/Kep/4/1999, tin mining activity at the center of the economy is limited and closely monitored so this condition impact to other sectors. The beauty of Bangka Belitung Islands is currently being transformed from green zone into wasteland because of illegal mining. Fertile land is turned into thousands of craters that become sources of malaria. Fish stocks and coral reefs are being destroyed by dredgers and tinsucking ships. Accidents happen weekly, with informal miners dying in landslides and in accidents on the bottom of the sea. These are all costs of tin production that are not being taken into account. It means that the tin mining isn't the best source of sustainable share to the Gross Domestic Product (GDP) for the future.

Since tin mining has been done for a long time without proper rehabilitation and good environmental management, tin mining in Bangka Belitung Islands has a negative net value 
for society. According to an evaluation by Indonesia's Environment Ministry year 2013, the net present value benefit from tin mining in West Bangka district was minus Rp 336 trillion ( $\$ 28.5$ billion) over the 2007 until 2012 period. This negative number is caused by the high costs of health impacts, payments for clean water as an alternative for polluted water, and funds needed to manage decreasing productivity in nonmining sectors such as agriculture and fishery, due to erosion and land pollution caused by mining activities. The negative impact on the environment is one of the main reasons why the activity of PT. Timah and other mines in the province should be limited. Per capita, people from Bangka-Belitung Islands are among Indonesia's top consumers of fish. Water, lake and river are the source of life but on the other hand the tin which is the top job supply in Bangka Belitung, make them wretched.

Tourism is the right solution that can save Bangka Belitung Islands from crisis. Tourism is known as one of the most important factors in the productivity of a national economy having significant multiplier effects in economic activity (Brida et.al, 2008). Bangka Belitung's geography is the main reason why tourism could generate the multiplier economy effect. Bangka Belitung's Islands has many small islands and two core islands which is Bangka Island and Belitung Island. Total island that has been named amounted to 470 pieces and only 50 islands are inhabited. Bangka Belitung Islands Province is largely a plateau, valley and a small portion of the mountains and hills. Lowland altitude average of about 50 meters above sea level and altitude mountain areas among others to Mount Maras reach 699 meters in District Belinyu of Bangka, Mount Sharp Leg height is approximately 500 meters above sea level on the island of Belitung. All of these advantages have shown on "Laskar Pelangi" movie and make these islands become one of the paradise island in Indonesia.

Learning from one of the countries in Europe which have similar characteristics with Bangka Belitung's Islands is precisely in the Greek island of Santorini, tourism in Bangka
Belitung Island is expected to be a key sector that can lift this province arose from delays where the tourism growth is always higher than the economic growth it self (Soebagy, 2012). Similarities between the characteristics of Bangka Belitung Islands and Greece may be seen in the geography, the region consists of islands and two large islands of Bangka and Belitung, and Mykonos \& Santorini. In addition, marine tourism and travel by respecting local culture also become the icon of tourism in both places.

This paper aims to (i) see the picture of tourism in Bangka Belitung Islands 2016; (ii) Assess Greek's policy of Tourism on the island of Santorini which could be applied in Bangka Belitung Islands; (iii) Viewed statistically whether the economy affect the tourism sector in the Bangka Belitung Island.

\section{METHODOLOGY}

The methods which are used to answer all the problems stated on previous chapter divided into 2 different approach, they are qualitative approach and quantitative approach. For the qualitative approach is described by Strength, Weakness, Opportunities and Threats (SWOT) table analysis. On the other hand, by generating simple linear regression method for the quantitative approach.

SWOT analysis is a structured planning method used to evaluate the strengths, weaknesses, opportunities, and threats involved in a project, organization, business venture, place, or industry. It involves specifying the objective of the business venture or organization and identifying the internal and external factors that are favorable and unfavorable to achieve that objective. Thus, it aims to identify the key internal and external factors seen as important to achieving an objective (Okumus et.al., 2010).

After identify the key factor, we need to measure how far the influence of tourism it self in Bangka Belitung Island to its economy. That's way in this paper, generating statistic model of simple linear regression was chosen after selective consideration. Simple linear regression 
defines the regression analysis as the study of the relationship of one variable is called a variable described (the explained variable) with one or two variables that explain (the explanatory). The first variable is also known as the dependent variable and the second variable is also known as the independent variable. If more than one independent variable, the regression analysis is called multiple linear regression. Known as the influence of some of the multiple independent variables are subject to the dependent variable.

The simple linear regression model can be expressed in this following equation:

$\boldsymbol{Y}_{\boldsymbol{i}}=\boldsymbol{\beta}_{\mathbf{0}}+\boldsymbol{\beta}_{\mathbf{1}} \boldsymbol{X}_{\boldsymbol{i}}+\boldsymbol{\varepsilon}_{\boldsymbol{i}} \quad(\mathrm{i}=1,2, \ldots, \mathrm{n})$

Where:

$\boldsymbol{Y}_{\boldsymbol{i}}$ is the value of the dependent variable on the $\mathrm{i}^{\text {th }}$ observation

$\boldsymbol{\beta}_{\mathbf{0}}$ and $\boldsymbol{\beta}_{\mathbf{1}}$ are parameter of model

$\boldsymbol{\varepsilon}_{\boldsymbol{i}}$ is the error component

$\boldsymbol{X}_{\boldsymbol{i}}$ is the value of the independent variable on the $\mathrm{i}^{\text {th }}$ observation

$\mathrm{n}$ is the number of observation

This paper using Gross Domestic Regional Product (GDRP) Bangka Belitung's Islands on 2004 until 2012 period as the dependent variable (Y) that obtained from BPSStatistics Indonesia. Then, the number of tourists which is composed of local and foreign travel is used as a independent variable (X) that represents tourism (Hamsani et al., 2015). This data obtained from the Department of Tourism and Culture of Bangka Belitung's Islands province 2004 until 2014 period. Later, it will be seen how the variables affect tourism Bangka Belitung Islands GDRP that describe the economy in this province. Running data using software Statistical Package for Social Science (SPSS) 20 version.

\section{RESULTS AND DISCUSSION}

The Power of Bangka Belitung Island Tourism

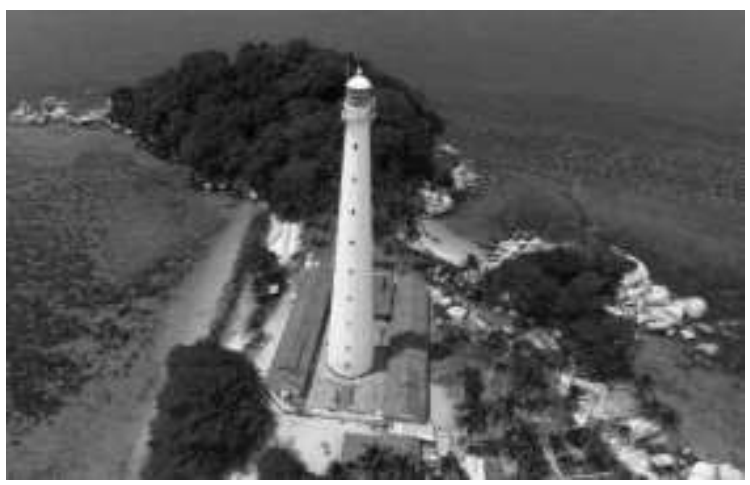

Figure 1. Mercu suar Pulau Lengkuas, Belitung Source: https://www.youtube.com/watch?v=itdvn7AwxQ accessed on 9 July 2018 @ tokiran channel

As an archipelagic province, Bangka Belitung Islands present the beauty of marine tourism in addition to various other tourist attractions such as the historical attractions and traditional events typical of Bangka Belitung. Excellence is attracting a number of tourists both domestic and abroad to come to this island. Over the past five years, the number of foreign tourists and domestic experience upward trend, from the beginning 192,695 tourists in 2011 to 305,436 in year 2015 (BPS-Statistics Bangka Belitung's Islands Province, 2016). Province that famous for tin and other dairy will have a variety of economic activity presented in the Table 1.

Table 1. Major products and activities

Tin, pepper, rubber, coconut, palm oil, agar wood, bauxite,

Primary monazite, ilmenite, zircon, hematite, quartz, sand, seaweed, and fish

Tin one smelting, kaolin, pepper,

Secondary rubber, palm oil, coconut, and fish processing

Tertiary Marine tourism

Source: Asia Competitiveness Institute, 2015 
Secondary sector contribution to the GDRP of Bangka Belitung's Islands amounted to $29.01 \%$ in 2011. Meanwhile, the tertiary sector contributes to the GDP amounted to 35.85 $\%$ in 2011 (Tan Khee Giap. et al., 2014). From these data, it is evident that the tertiary sector has potential nautical tourism for tourism development which in turn positively affect Bangka Belitung's economic. The province is also part of the route of tourism "Cheng Ho Sea Route: Archipelago Sailing", who was unveiled by the Minister of Tourism, Arief Yahya in 2015. This effort in order to increase tourism by attracting

Chinese tourists who are interested in the influence of Chinese culture on the culture of Indonesia but still maintain the local culture.

Bangka Belitung's Islands has a good reputation for tourism in Indonesia, and it has been a destination for Sail Belitung that attracts many domestic and international tourist come to visit this island. In addition, Belitung still has many beautiful natural places, such as Tanjung Pendam Beach, Tanjung Tinggi Beach, Pasir Island, Lengkuas Island, Tanjung Kelayang Beach, Gurok Beraye, Batu Mentas, Kolong Keramik, Kolong Murat, etc (Belitung Tourism, 2016). There was also a marine tourism white sand beach "Pasir Padi" in Suangailiat on Bangka Island.

On the other hand, Bangka Belitung Islands has supported air transportation, which is about 13 flights to Bangka Island and 8 until 9 flights to Belitung per day from capital city of Indonesia, Jakarta. The time duration is approximately 45 until 60 minutes for each airport. And then, potential fisheries, seaweed, and agriculture should provide good intensives for miners to look for alternative sources of income, as long as there is sufficient investment in the development of arable land, and seaweed farming fish. Their traditional party became a phenomenon of interest for tourists. Traditional feast depicts the authenticity and wisdom people Bangka Belitung Islands is still thick with their ancestral culture, such as the Feast of Prayer Seize Indigenous, Indigenous Hamlet New Power Party, Party Tribal Ketapik, and many other custom party.

However, the government should be involved in tourism because of the necessary arrangements regarding the procedures and regulations of the local government (Mill \& Morisson, 1985). Serious program that ever conducted of local governments is visit "Bangka Belitung Archipelago" in 2010 or last eight years ago. The government's efforts in improving tourism facilities considered to be quite significant. However, it takes a faster accelerated again in order to trigger and stimulate the preparation of the tourism sector in Bangka Belitung. Based on ACI's competitiveness, infrastructure development is the worst indicator of Bangka Belitung's Islands into weakness ${ }^{7}$. Bangka Belitung Islands need to improve facilities and critical infrastructure. Based infrastructure needs to be upgraded to support the review of secondary and tertiary sectors in order to thrive in this province. In addition, the province needs

to pay attention to education in order to create human resources who understand the sector tourism. All over describe in this SWOT Table 2. 
Table 2. SWOT Analysis of tourism in Bangka Belitung's Islands

\begin{tabular}{|c|c|}
\hline Strengths & Weakness \\
\hline Natural and cultural resources & Local Government Management \\
\hline Easily accessible from the capital of Indonesia, & Electricity \\
\hline Jakarta & Public transport \\
\hline Access road is good & Lack of investment \\
\hline It has a pure white sand beach & Human resources competent \\
\hline seafood culinary reliable & Small industry like souvenirs supporting tourism are \\
\hline custom culture events of the region & still few in number \\
\hline & travel guides with multi languages are still rare \\
\hline Opportunities & Threats \\
\hline Supported by the national film such as Laskar & Environmental degradation as a result of tin mining \\
\hline Pelangi and a famous writer named Andrea Hirata & The global economic slowdown and commodity \\
\hline Pulau Belitung set as Special Economic Zones or & prices, especially tin has not improved \\
\hline KEK (Kawasan Ekonomi Khusus) pariwisata by PP & Damage to the marine ecosystem as a result of \\
\hline No 6 th 2016 & mining activities \\
\hline $\begin{array}{l}\text { Being one of the world namely the occurrence of } \\
\text { rare events (Total Eclipse of the sun) GMT }\end{array}$ & \\
\hline Low cost living & \\
\hline
\end{tabular}

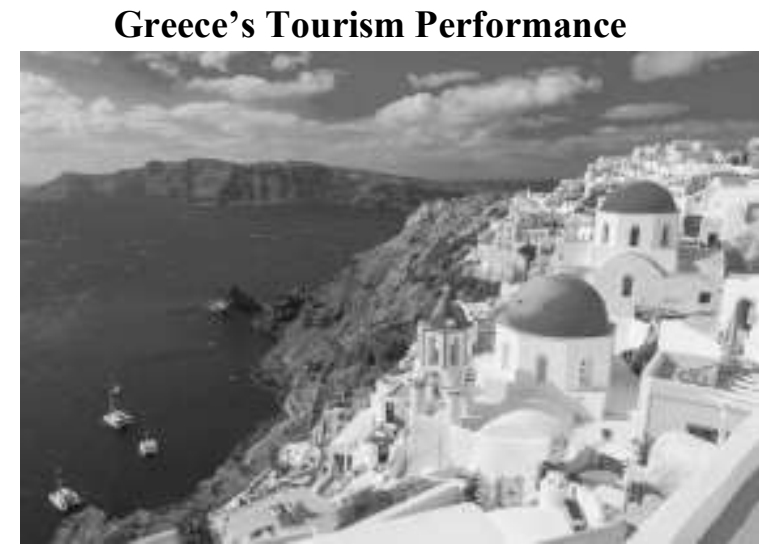

Santorini Beach

Sources : http://www.kevinandamanda.com/santorinigreece/ accessed on 9 July 2018

Actually Greece has shown us how to make tourism become the led sector to GDP. Greece is one of top ranked country based on the competitiveness rankings for tourism infrastructure, prioritization of travel and tourism, and national tourism perception (Kayar, 2008). Moreover the geography of Greece has a lot in common with Bangka Belitung. Greece has successfully made the tourism sector as one of the largest contributors to GDP. Tourism sector is also believed to generate the economy after the global crisis that hit Greece a few years ago. It represents an important economic activity and was less affected by the global economic crisis than other economic sectors. Besides resistant to the economic crisis, the tourism sector is an effective solution without having to make a large negative impact on the environment.

Tourism is the heavy industry, it is the main economic source of income today and also the main source of jobs for many Greeks. The total contribution of Travel \& Tourism to employment (including wider effects from investment, the supply chain and induced income impact was 700,000 jobs in 2014 (19.4 $\%$ of total employment). Almost $20 \%$ of whole economy employment is provided by this sector. It indicates tourism and travel are a firm sector in Greece ${ }^{8}$. By 2025, Travel and tourism is forecast to 951,000 jobs $(22.2 \%$ of total employment), an increase of $2.7 \%$ over the period as seen on the Figure 2 below. 


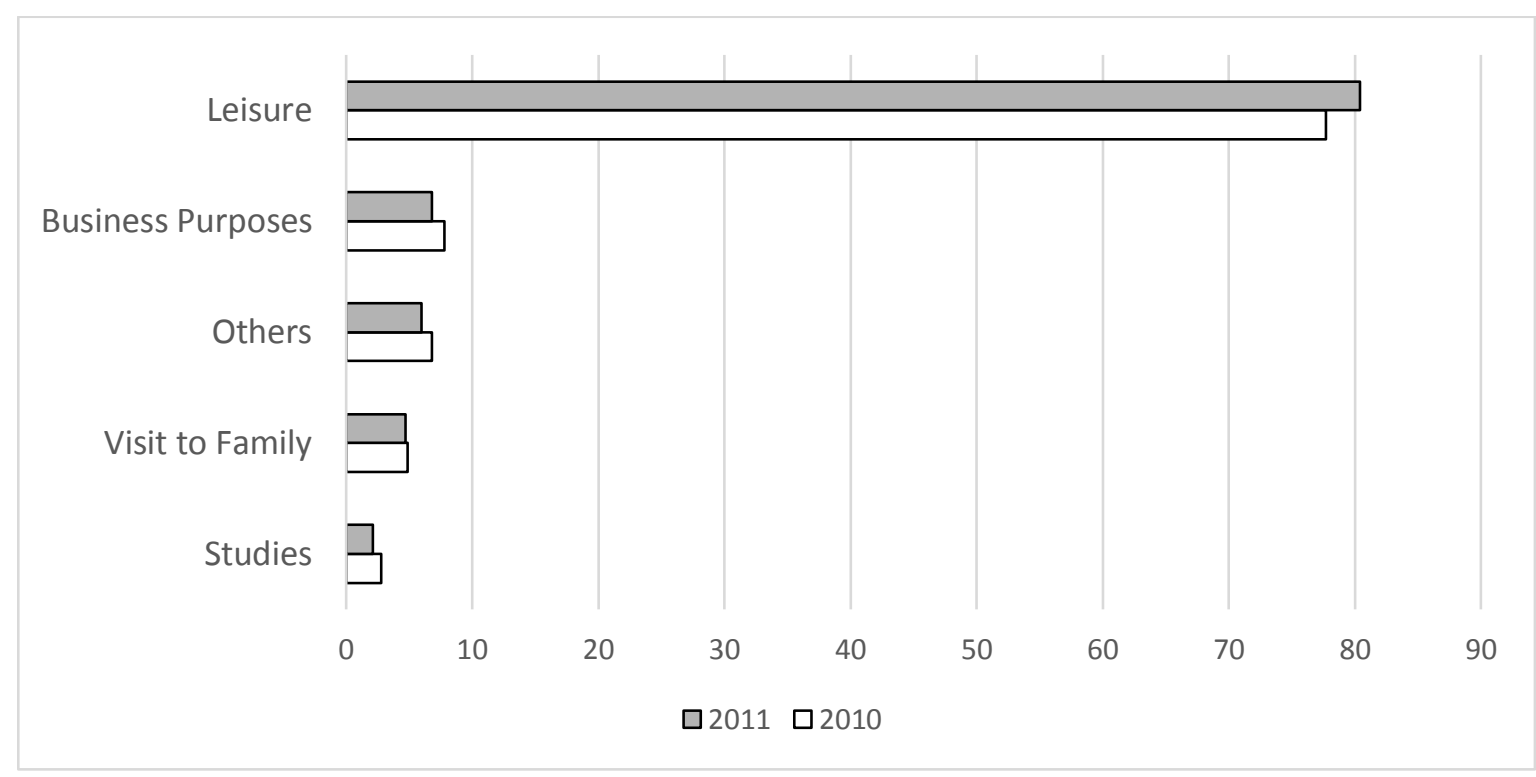

Figure 2. Travel receipts by purpose of visit Source: Bank of Greece

According to the same references, some researches had constructed the SWOT analysis of Greece tourism. Natural resources and local character become the strengths of Greek tourism. Almost of all the Greek tourism's strengths has a lot in common with Indonesia's culture. The weaknesses is almost similar to Indonesia's except seasonality, because Indonesia has tropical climate, tourist could enjoy the beautiful scene for the entire years. Like Greece, Indonesia is often become major sporting event in Asia, even on 2018 Indonesia is a host of Asian Games 2018 that held in Jakarta and Palembang. Both are next to Bangka Belitung Islands. It's possible before or after Asian Games begins, all supporters around Asia will visit Bangka Belitung Islands for vacation.

Greece, despite all its economic and political strife, is heaving with foreign tourists.
Greece offer historical, cultural, ancient and lovely vacation for family. Bank of Greece has revealed that travel receipts by purpose of visit is dominated by leisure purpose. By this graph below, it's not wonder if tourism is a ledsector of GDP support. This graph indicates the geography of Greece has an advantages for tourism industry.

One of the region in Greece named Cyclades has a lot in common characteristic with Bangka Belitung islands. Not only the archipelago but also the climate is dry among the year between both. The Cyclades region is divided into Mykonos \& Santorini just like Bangka and Belitung. But in this occasion, the focus object is Santorini because it is the beauty of Greece itself. Although having many similarities between Bangka Belitung Islands and Santorini, but the performances of tourism on both are totally different. The gap could be seen in the Figure 2. 


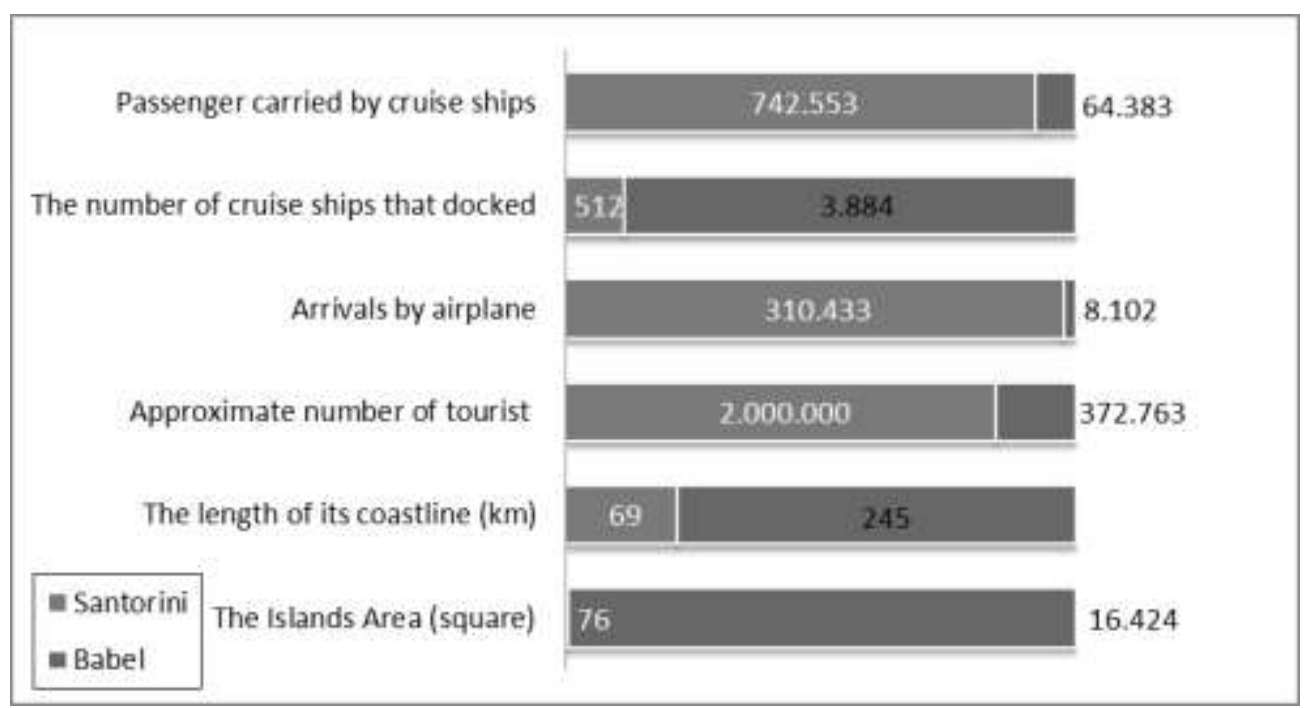

Figure 3 The Gap between Santorini and Bangka Belitung based on Tourism Factor 2014 Sources: Babel in Figures, 2016 and Santorini in Number, 2015

Actually the demography of Bangka Belitung Islands is better than Santorini (described by red bar in area and length of coastline are larger than blue one), but the management of tourism in Santorini could attract more tourist. The traffic's Santorini on transportation by airplane and cruise ship is more crowded than Bangka Belitung Island (the blue bar larger than red bar at the first four factors). A factor that make Bangka Belitung Island is superior than Santorini in transportation is the number of cruise ships docked only. It's caused by many ship docked in Bangka Belitung to carry the tin by PT Timah.

\section{The Icon of 4S in Santorini}

All Mediterranean countries like Greece especially focus in Santorini, adopted and implemented more or less the same model of tourism development based on 4S (Sun, Sea, Sand and Sex). In analyzing the experience of developing leisure tourism in Santorini, here is the detailed 4S that Santorini proud of and what we can learn from them.

\section{Sun}

The island are peaks of submerged mountainous terrain, with the exception of two volcanic islands, Milos and Santorini. Agricultural production includes wine, fruit, wheat, olive, oil, and tobacco. The climate is generally dry and mild. Cooler temperatures are recorded in higher elevations and Cyclades generally do not receive heavy winters. All roads in the island complex are secondary or provincial. Just as Bangka Belitung Islands, hot tropical climate that presents the beauty of the sunrise and sunset for tourists. On the island of Bangka also has Mount Menumbing historical value because it had become a place of exile first president of Indonesia.

\section{Sea}

Santorini island is a popular island destination around the globe that offers several attractions to the tourist, such as the volcano and the archipelago views, the Ancient City of Thira, the boat trip around the volcano, the archaeological site of Akrotiri, (functional again since October 2012 after the restoration of the collapsed roof of the archaeological site), and numerous beaches, three of which are awarded with the Blue Flag. Santorini also features several museums, most popular being the Prehistoric and the Archaeological one.

Similarity can also be seen here, Bangka Belitung Islands have a unique museum the only one in Indonesia, namely Museum Kata Andrea Hirata. As for the beauty of its beaches, no doubt due in Bangka Belitung Islands tourists can snorkeling in crystal clear sea water and beautiful blue. 


\section{Sand}

Santorini is a small, circular archipelago of volcanic islands located in the south Aegean Sea, about $200 \mathrm{~km}$ south-east from Greece's mainland. It is also known as Thera (or Thira), forming the southernmost member of the Cyclades group of islands, with an area of approximately $73 \mathrm{~km}^{2}$ and a population of 13,670 (2011 census). It has a total land area of more than $90 \mathrm{~km}^{2}$ including the uninhabited islands of Nea Kameni, Palala Kameni, Aspronisi, and Christiani. Santorini is essentially what remained from an enormous volcanic explosion, destroying the earliest settlements on what was formerly a single island, and leading to the creation of the current geological caldera. Same here, in Bangka Belitung's Islands all existing beach has white sand so as to be excellent because of its authenticity. In fact, there is a beach called "Pasir Padi". This beach has white sand and clean.

\section{Sex}

Santorini has successfully managed to be positioned as a primary destination for upscale weddings and romantic honeymoons. Due to its unique beauty enhanced by the volcano and the breath taking views to the Aegean Sea, and its famous sunset, the island is well-positioned towards the niche market of weddings and honeymooners as an ideal destination. Santorini is served by one airport, that accommodates, in addition to the regular national flights, international charter flights during summer when tourist visitation usually peaks. Many tourists without clothes in a certain season to enjoy the beautiful beaches in Santorini. They are free to have sex in public places and revealing clothes.

Tourism is an economic activity with cultural outcomes (Shah, 2008). Sex is the advantage of tourism effect which is being less appropriate when incorporated into Indonesia tourism that embraces the eastern culture. Sex is seen as negative, unless the goal is for honeymoon couples who have been legitimate. This is what needs to be adopted from Santorini. Bangka Belitung Islands offers Sea Food in lieu of all four elements of the "4S" -Santorini. Seafood is the right choice for the majority of the population in the Bangka Belitung Islands where most of population work in the fisher sector. The catch sea was diverse, ranging from fish to seaweed. In fact, the results showed the weakness of infrastructure and facilities in Pasir Padi, Bangka Belitung Islands only seafood restaurant that gets a good response from the tourists with a percentage of $49.0 \%$. While most of the other facilities were getting a poor response and enough of the tourists. Another fact that shows the seafood could be excellent Bangka Belitung Islands is the level of fish consumption society which is above the level of national consumption. If in Indonesia, fish consumption of $33.5 \mathrm{~kg}$ per capita per year, the consumption level of the Bangka Belitung Islands community has reached $46 \mathrm{~kg}$ per capita per year. It shows the availability of seafood in Bangka Belitung Islands is large enough.

Other reason why Bangka Belitung Islands has potential natural resources for tourism describe by this statistic data:

(i) The only way to see how potential the tourism in Bangka Belitung is by looking at the number of International and Domestic visitors in Bangka Belitung Islands Province. Based on BPS Data from 2012 until 2015, there always be an increase in the number of visitors and the recent is $126.15 \%$ in 2015 . Not only that, the average length of stay domestic visitors for 2.11 days and international visitors for 1.76 . It tells us a lot that the tourist come to Bangka Belitung Islands to enjoy the view, the beach, and spending money for holiday not just for business.

(ii) By implementing the $4 \mathrm{~S}$ tourism strategy in Bangka Belitung Islands like The Greek did, it could be a magnet for attracting tourist to visit Bangka Belitung. The potency of 4S (sun, sea, sand, and seafood) is very supportive. BPS notes that the climate of Bangka Belitung Islands supports the 4S Tourism Strategy here. With the average temperature $28.10{ }^{\circ} \mathrm{C}$ in Bangka and $22.80{ }^{\circ} \mathrm{C}$ in Belitung Island, it suits the tourist to enjoy the nature without worrying about an extreme climate. The best part in Bangka Belitung Islands is the duration of sunshine in the 
both island. $41 \%$ in Bangka and $49.2 \%$ in Belitung make tourist could go sightseeing longer in the midday. They could go swimming, shopping, having seafood in a full day because the climate is very supportable.

(iii) The last but not least is how the tourism affect the Economy, GDRP in this case. The effect of tourism to the Bangka Belitung Islands GDRP could be described by using a simple linear regression. the tourism's effect on Bangka Belitung Islands GDRP in 2004 until 2014 can be analyzed using this method. The output result is below:

Table 3. Output of Running regression Using SPSS 20

\begin{tabular}{|l|r|r|r|r|r|}
\hline \multirow{2}{*}{ Model } & \multicolumn{2}{|c|}{$\begin{array}{c}\text { Unstandardized } \\
\text { Coefficients }\end{array}$} & $\begin{array}{c}\text { Standardized } \\
\text { Coefficients }\end{array}$ & t & Sig. \\
\cline { 2 - 6 } & \multicolumn{1}{|c|}{$\mathrm{B}$} & Std. Error & Beta & & \\
\hline (Constant) & 10224972 & 2175723,6 & & 4,700 & 0,00 \\
\hline Tourism & 106,091 & 12,996 & 0,939 & 8,163 & 0,00 \\
\hline
\end{tabular}

a. Dependent Variable : GDRP

From Table 3, the estimated model is:

$$
\widehat{G D R P}=10224971.51+106.09 \text { Tourism }
$$

Tourism variable coefficient is positive $(+106.09)$, it means that tourism has a positive impact on the increase GDRP. If the rise of tourism variable, then the variable indicating GDRP as economic conditions Bangka Belitung Islands also rise. Each rating rise one person, then it is assumed GDRP rise by 106.09 rupiah, therefore, the increase in the tourism sector which is characterized by an increase in travelers to Bangka Belitung Islands province will increase local revenue of the province. With a $\mathrm{p}$ value of 0.000 , the tourism sector is statistically significant influence Bangka Belitung's Islands GDRP with a 95\% confidence level. From the model, obtained R-Square is 0.8810 (quadrat of Standardized Coefficient) which means that the tourism sector can account for 88.10 percent GDRP so obtained regression model was appropriate.

\section{CONCLUSIONS AND RECOMMENDATIONS}

Tourism-led growth is possible for many least developed countries. The variety of goods and services involved in the tourism supply chain leads to a broad impact in terms of poverty reduction. But it also requires a commitment from the private sector and the public sector to work together in the development of sustainable tourism for local benefit. Policymakers, privatesector investors, and community players all must be involved to create the right kind of framework. In emphasizing the necessity to think about different approaches and the importance of the private sector in generating growth and creating jobs.

The main lessons that could be drawn from the above analysis is that Bangka Belitung's Islands has great potential on tourism: it could have performed better if there was an appropriate tourism planning and rational policy. Repair facilities supporting tourism development should be accelerated. Its main focus should be the public transportation to easy access tourism destination. The main strategic aim is to use "4S" (Sun, Sea, Sand, Seafood) for marketing.

\section{REFERENCES}

Belitung Tourism. (2016). Available at: http://disparekraf.belitungkab.go.id [16 January 2018]

BPS - Statistics Bangka Belitung's Islands Province. (2016). Bangka Belitung's Islands in Figures

Brida, J. B., Carrera, E. J. S., Risso, W. A. \&, Schubert, S. F. (2008). Tourism Impact in the Long Run Mexican Economic. Proceeding of The 4th World Conference for Graduate Research in Tourism, Hospitality and Leisure. 22 - 27 April 2008, Antalya, Turkey 
Hamsani \& Valeriani. (2015). Blue Ocean Strategy : Pengembangan Pariwisata di Provinsi Kepulauan Bangka Belitung. Jurnal Ekonomi Akutansi dan Manajemen, 13 (2), 1-45

Kayar, C. H. \& Kozak, N. (2008). Measuring Destination Competitiveness: An Application of Travel and Tourism Competitiveness Index. Journal of Hospitality Marketing \& Management, 19 (3), $72-85$

Mill, R. C., \& Morrison, A.M. (1985). The Tourism System. Englewood Cliffs: Prentice Hall, 200-203

Okummus, F., Altinay, L. \& Chathoth, P. (2010). Strategic Management for Hospitality and Tourism, 20-25. Oxford: ButterworthHeinemann

Shah, T. (2008). Where Tourism Runs the economy and Shapes the Culture. Proceeding of The 4th World Conference for Graduate Research in Tourism, Hospitality and Leisure. 22 - 27 April 2008, Antalya, Turkey

Soebagyo. (2012). Strategi Pembangunan Pariwisata di Indonesia. Jurnal Liquidity, 1(2), 153-158

Tan, K. G., Merdikawati, N., Amri, M. \& Berger, B. H. (2014). Chapter 33: South Sumatera. 2014 Annual Competitiveness Analysis and Development Strategies for Indonesian Provinces. World Scientific Publishing 